Available online on 15.07.2018 at http://jddtonline.info
Journal Of Drug Delivery and Therapeutics
$\begin{gathered}\text { Open Access to Pharmaceutical and Medical Research } \\ \text { 2011-18, publisher and licensee JDDT, This is an Open Access article which permits unrestricted non- } \\ \text { commercial use, provided the original work is properly cited }\end{gathered}$

Open

\title{
IN VITRO TOXICITY STUDIES ON THE EXTRACT OF MEDICINAL PLANT EVOLVULUS NUMMULARIUS AS A POTENT MICROBICIDAL CANDIDATE
}

\author{
Basu-Mullick Jhinuk ${ }^{1}$, Reddy KVR ${ }^{2}$, Saha Susmita ${ }^{1}$, Bashir Tahir $^{2}$, Hore Samrat ${ }^{3}$, Sil Samir Kumar ${ }^{1}$ * \\ ${ }^{1}$ Molecular Genetics and Cell Physiology Lab, Department of Human Physiology, Tripura University, Agartala, Tripura, India \\ ${ }^{2}$ Division of Molecular Immunology \& Microbiology, National Institute of Research in Reproductive Health (ICMR), Mumbai, \\ Maharashtra, India \\ ${ }^{3}$ Department of Statistics, Tripura University, Agartala, Tripura, India
}

\begin{abstract}
The herb Evolvulus nummularius (L). L generally grown as an ornamental plant has found many applications in traditional folk medicine. There was however insufficient scientific data to back its safety to be used on humans. Methanolic extract of $E$. nummularius was used to check for its safety as a vaginal microbicide through various safety tests such as cell viability using MTT assay on three female genital tract epithelial cell lines, vaginal (VK2/E6E7), endocervical (End1/E6E7) and endometrial (HEC-1-A). Quantification of hemolytic activity was done on human red blood cells (RBCs). Determination of cellular integrity was checked by transepithelial electrical resistance (TER) assay and permeability by fluorescent microsphere assay. At 24 hours, application of the extract for cell viability assay showed extensive cell death with cell disruption. IC $_{50}$ of VK2/E6E7 and HEC-1-A cells were found to be $2 \mathrm{mg} / \mathrm{ml}, \mathrm{IC}_{50}$ of End1/E6E7 was $1 \mathrm{mg} / \mathrm{ml}$. For hemolytic assay, with treatment of the extract for one hour did not show hemolysis till the concentration of $2.5 \mathrm{mg} / \mathrm{ml}$. In TER and microsphere permeability assays, polarized HEC-1-A monolayer 24 hours post treatment had significant drop in TER and enhanced fluorescence from passage of microspheres implying disruption of the epithelial monolayer. The study revealed that the crude methanolic extract appeared to be toxic towards human RBCs and female genital tract epithelial cells. Due to its toxic nature, its direct applications to the human vaginal tissue in vivo should be done with caution.
\end{abstract}

Keywords: Medicinal plants; Microbicide; Evolvulus nummularius (L). L; MTT assay; Transepithelial electrical resistance; Fluorescent microsphere assay.

Article Info: Received 02 May, 2018; Review Completed 26 May 2018; Accepted 27 May 2018; Available online 15 July 2018

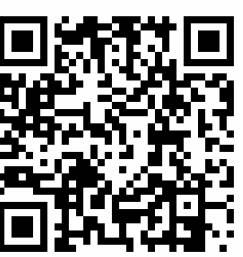

Cite this article as:

Basu Mullick J, Reddy KVR, Saha S, Bashir T, Hore S, Sil SK, In-vitro toxicity studies on the extract of medicinal plant Evolvulus nummularius as a potent microbicidal candidate, Journal of Drug Delivery and Therapeutics. 2018; 8(4):229-236 DOI: http://dx.doi.org/10.22270/jddt.v8i4.1778

*Address for Correspondence:

Samir Kumar Sil, Department of Human Physiology, Tripura University, Agartala, Tripura, India

\section{INTRODUCTION}

Before synthetic drugs became popular, medicines were obtained from natural sources such as plants, animals and microbes. Herbal medicines have passed down through ages being considered as safe. Even today plant parts are eaten, used for cosmetic purpose and as medicines without proper knowledge if they are toxic. As per WHO estimates at present $65-80 \%$ of the world population relies on herbal medicines ${ }^{1}$. It is naive to consider however, that since these plants have been consumed as food or are being used as herbal products they are safe. As per the review of Lanini et al. "if herbs have an effect, they are also likely to have a side effect". The toxicity or safety of any substance derived from nature depends on several factors such as its route of administration, dosage and period of time the medicine is active. In most countries plant based medicines are sold as dietary supplements and therefore 
safety and regulatory studies essential for drugs have never been applied for many a medicinal plant.

Evolvulus nummularius (L). L (Syn. Convolvulus nummularius L., L.) though generally grown as an ornamental plant, has found many applications in traditional folk medicines to cure burns, cuts, hysteria, scorpion stings ${ }^{3}$. In Nepal, its paste has been used to treat scabies. ${ }^{4}$ It is also known to possess wound healing properties. $^{5}$ Study dating back to 1964 revealed anticonvulsant and sedative properties in $E$. nummularius. ${ }^{6}$ A paste made of E. nummularius along with other plants is used in the treatment of peptic ulcer. $^{7}$ The herb is also known to be applied to legs to reduce edema during pregnancy. ${ }^{8}$ Activity of $E$. nummularius against standard Gram-positive and negative bacteria has been reported by Pavithra, Sreevidya and Verma. ${ }^{9}$ Dash et al. ${ }^{10}$ reported its antihelminthic activity, and Saha, Dinda, and $\mathrm{Sil}^{11}$ reported its activity against parasite Leishmania donovani.

Since the plant has shown extensive medicinal properties, we intended to test its usefulness as a vaginal microbicide against sexually transmitted pathogens. There was however insufficient scientific data to back its safety to be used on human tissues. E. nummularius therefore was found to be an interesting candidate requiring detailed safety studies both for application as a microbicide, as well as to know the safety of its application for its reported other medicinal activities.

\section{MATERIALS AND METHODS}

\section{Plant collection and authentication}

Fresh whole plants including roots of E. nummularius were collected from the Tripura University campus at Suryamaninagar, Agartala, Tripura, India. The plant was initially identified by Prof. B. K. Datta, Taxonomist, Department of Botany, TU and finally authenticated by Dr. H. J. Chowdhery, Joint Director, Central National Herbarium, Botanical Survey of India, Shibpur, Howrah, West Bengal and voucher specimen No. (\#BD05/05) was deposited in the Central National Herbarium, Botanical Garden, Shibpur, Howrah, West Bengal, India.

\section{Preparation of extract}

Collected whole plants including roots were washed and air dried for three weeks. They were then ground and 5 kilo grams of ground plant parts were macerated with 15 liters of methanol for $48 \mathrm{hrs}$. The extract was then filtered and evaporated in a rotary evaporator (Hahn Shin Scientific Corporation, South Korea). At the end of this the extracts were left to air dry for a week at $4^{\circ} \mathrm{C}$ to remove more traces of the solvent. Finally, methanolic extract of E. nummularius (MEEN) was dissolved in double distilled water at a stock concentration of 100 $\mathrm{mg} / \mathrm{ml}$.

\section{Cell lines and cultural conditions}

VK2/E6E7 and End1/E6E7 two keratinocyte cell lines developed from vaginal and endocervical tissues respectively were kind gifts from Dr. Fichorova. HEC1-A cell line established from human endometrial adenocarcinoma $^{12}$ was procured from National Center for Cell Science, Pune, India. VK2/E6E7 and End1/E6E7 cell lines were maintained in keratinocyte serum-free medium and HEC-1-A was cultured in McCoy's 5A (modified) medium ${ }^{13}$.

\section{Determination of cell viability using MTT assay}

Cell viability was determined using MTT \{3-(4,5dimethylthiazol-2-yl)-2,5-diphenyltetrazolium bromide $\}$ as per previous protocol of Sathe and Reddy. ${ }^{14}$ Briefly, VK2/E6E7, End1/E6E7 were incubated in $100 \mu \mathrm{L}$ KSFM and HEC-1-A cells in $100 \mu \mathrm{L}$ McCoy in 96-well plates for $24 \mathrm{hrs}$. Then, $100 \mu \mathrm{L}$ from $24 \mathrm{mg} / \mathrm{ml}$ stock concentration of plant extract was added in row $\mathrm{A}$. The $200 \mu \mathrm{L}$ of solution $(100 \mu \mathrm{L}$ drug $+100 \mu \mathrm{L}$ media $)$ were mixed and $100 \mu \mathrm{L}$ from row A were added into next row (row B) by using micropipette and a serial dilution was done up to row G. Finally, excessive $100 \mu \mathrm{L}$ from row $\mathrm{G}$ were discarded. The final volume for each well was $100 \mu \mathrm{L}$. As a positive control for cytotoxicity, $10 \mu \mathrm{L}$ of $0.1 \%$ Triton X-100 (TX) was added. An untreated negative control (UT) well with only cells and media was also included. At the end of the $24 \mathrm{hrs}$ treatment time point cells were washed thrice with PBS ( $\mathrm{pH} 7.2$ ). MTT $(0.5 \mathrm{mg} / \mathrm{ml})$ was added next for $3 \mathrm{hrs}$ at $37^{\circ} \mathrm{C}$, following which cells were morphologically observed for analyzing changes induced by the extracts. Cells in each well were then solubilized in $100 \mu \mathrm{L}$ dimethyl sulfoxide (DMSO). Reduction of MTT to formazan crystals within cells was quantified by measuring optical density at $570 \mathrm{~nm}$ using Synergy H1 microplate reader (BioTek Instruments) and percentage cell viability calculated as percentage of average absorbance of duplicate drug wells divided by average absorbance of control wells. $\mathrm{IC}_{50}$ was calculated as per the protocol of Vijayarathna and Sasidharan. ${ }^{15}$

\section{Determination of transepithelial electrical resistance (TER)}

In vitro determination of cellular integrity was done through TER measurement of HEC-1-A cell monolayer as per the protocol of Sathe and Reddy. ${ }^{14}$ HEC-1-A cell line was used to prepare cell monolayer. $200 \mu \mathrm{L}$ and 900 $\mu \mathrm{L}$ of McCoy media with supplements were added in the apical and basal compartments respectively and changed every alternate day. Transwell inserts were cultured at $37^{\circ} \mathrm{C}$ in a humidified atmosphere of $5 \% \mathrm{CO}_{2}$ for 7- 8 days until confluent monolayer of HEC-1-A cells were formed. TER (Millicell ERS Ohmmeter, Millipore) of the established polarized monolayer was measured daily till the $8^{\text {th }}$ day. The net TER was calculated by subtracting the background and multiplying the resistance by the area $\left(1.12 \mathrm{~cm}^{2}\right)$ of the filter. Upon formation of confluent monolayer on the $8^{\text {th }}$ day, HEC-1-A cells were treated with the extract. Each Transwell insert was subjected to one treatment: untreated control (UT), MEEN (T-En1.0) at a concentration of $1 \mathrm{mg} / \mathrm{ml}$, and positive control for cytotoxicity treated with $0.1 \%$ Triton X-100 (TX). The treatments were given for $24 \mathrm{hrs}$, post which TER was measured to observe for any drop in resistance. 


\section{Fluorescent microsphere assay}

Permeability assay using fluorescent microspheres of the size of HIV virus particles was done as per the protocol of Gali et al. ${ }^{16}$ To the polarized HEC-1-A cell monolayers set up in Transwell units upon reaching confluency, treatments were divided into three groups: untreated control (UT), MEEN (T-En1.0) in concentration of $1 \mathrm{mg} / \mathrm{ml}$, and positive cell death induced by $0.1 \%$ Triton X-100 (TX). Yellow green fluorescent microspheres of diameter $0.1 \mu \mathrm{m}$ were then added in the volume of $100 \mu \mathrm{L}$ (approx. $1.8 \mathrm{x}$ $10^{4}$ beads). Post treatment for $24 \mathrm{hrs}, 200 \mu \mathrm{L}$ of media from the basal chamber was harvested and fluorescence was measured at $486 \mathrm{~nm}$. Fluorescence emitted by beads that crossed the treated monolayer as compared to the no treatment control with intact monolayer was plotted as percentage fluorescence and level of significance analyzed.

\section{Hemolytic assay}

$5 \mathrm{~mL}$ of fresh human red blood cells (HRBCs) was obtained from a healthy donor in a polycarbonate tube containing heparin. The hemolytic activity of MEEN was evaluated as described previously. ${ }^{17}$ The release of hemoglobin after 1 hour of incubation was measured by monitoring optical density at $576 \mathrm{~nm}$. Untreated HRBC suspension was used as a negative control (UT), and the HRBCs treated with $0.1 \%$ Triton X-100 (TX) was employed as a control positive to bring about hemolysis. Percent hemolysis was calculated using the equation given below and the concentration of extract which caused $10 \%$ hemolysis was taken as the minimum hemolytic concentration.

Hemolysis $(\%)=$

$$
\text { O.D.576nm of the treated sample - O.D.576nm of the negative control) }
$$

(O.D. $576 \mathrm{~nm}$ of the positive hemolysis inducer - O.D ${ }_{.576 \mathrm{~nm}}$ of the negative control)

\section{Statistical analysis}

All data were calculated as the mean value \pm standard deviation (SD) from three independent experiments performed on different days. The significant effect of each treatment with respect to untreated control was carried out through $\mathrm{t}$ test at various significance levels $(* \mathrm{p}<0.05 ; * * \mathrm{p}<0.01)$.

\section{RESULTS}

\section{Determination of cell viability by MTT Assay}

The effects on viability of three cell lines after treatment with MEEN were assessed through the MTT assay.
Multiple concentrations of MEEN were used and the results of percentage viability at each concentration are as shown in Table 1. Dose-response curve was plotted against each concentration to enable the calculation of the concentrations that kill $50 \%$ of the cells $\left(\mathrm{IC}_{50}\right)$ as shown in Fig. 1. MEEN showed cell viability in the range of $34 \%-54 \%$, and its $\mathrm{IC}_{50}$ was determined to be 2 $\mathrm{mg} / \mathrm{ml}$ for VK2/E6E7 and HEC-1-A cell lines and 1 $\mathrm{mg} / \mathrm{ml}$ for End1/E6E7 cell line.

Fig. 2 shows microscopic observations of VK2/E6E7 cells with various treatment post MTT assay.

Table 1: Viability assay of vaginal, endocervical and endometrial cell lines after 24 hrs treatment with MEEN as determined through MTT assay. Absorbance was measured at $570 \mathrm{~nm}$. Values are calculated as mean \pm SD of three independent experimental trials.

\begin{tabular}{|l|c|l|l|l|l|l|}
\hline \multirow{2}{*}{$\begin{array}{l}\text { Concentration of } \\
\text { MEEN }(\mathrm{mg} / \mathrm{ml})\end{array}$} & \multicolumn{3}{|c|}{ Absorbance (Mean \pm SD) } & \multicolumn{3}{c|}{ Viability (\%) } \\
\cline { 2 - 7 } & VK2/E6E7 & End1/E6E7 & HEC1A & VK2/E6E7 & End1/E6E7 & HEC1A \\
\hline 1.00 & $0.292 \pm 0.03$ & $0.239 \pm 0.06$ & $0.289 \pm 0.01$ & $51.14 \%$ & $50.05 \%$ & $54.12 \%$ \\
\hline 2.00 & $0.286 \pm 0.01$ & $0.238 \pm 0.01$ & $0.28 \pm 0.03$ & $50.03 \%$ & $49.89 \%$ & $52.46 \%$ \\
\hline 3.00 & $0.276 \pm 0.01$ & $0.215 \pm 0.03$ & $0.264 \pm 0.01$ & $48.29 \%$ & $45.17 \%$ & $49.38 \%$ \\
\hline 6.00 & $0.225 \pm 0.07$ & $0.2 \pm 0.02$ & $0.252 \pm 0.01$ & $39.37 \%$ & $41.88 \%$ & $47.14 \%$ \\
\hline 12.00 & $0.195 \pm 0.01$ & $0.173 \pm 0.02$ & $0.25 \pm 0.02$ & $34.15 \%$ & $36.24 \%$ & $46.90 \%$ \\
\hline Untreated & $0.571 \pm 0.02$ & $0.477 \pm 0.02$ & $0.534 \pm 0.03$ & $100 \%$ & $100 \%$ & $100 \%$ \\
\hline Triton X-100 & $0.111 \pm 0.03$ & $0.05 \pm 0.03$ & $0.095 \pm 0.04$ & $19.37 \%$ & $10.46 \%$ & $17.78 \%$ \\
\hline IC $\mathbf{5 0}$ (mg/ml) & \multicolumn{7}{|l|}{} & & $\mathbf{2 . 0 0}$ & $\mathbf{1 . 0 0}$ & $\mathbf{2 . 0 0}$ \\
\hline
\end{tabular}




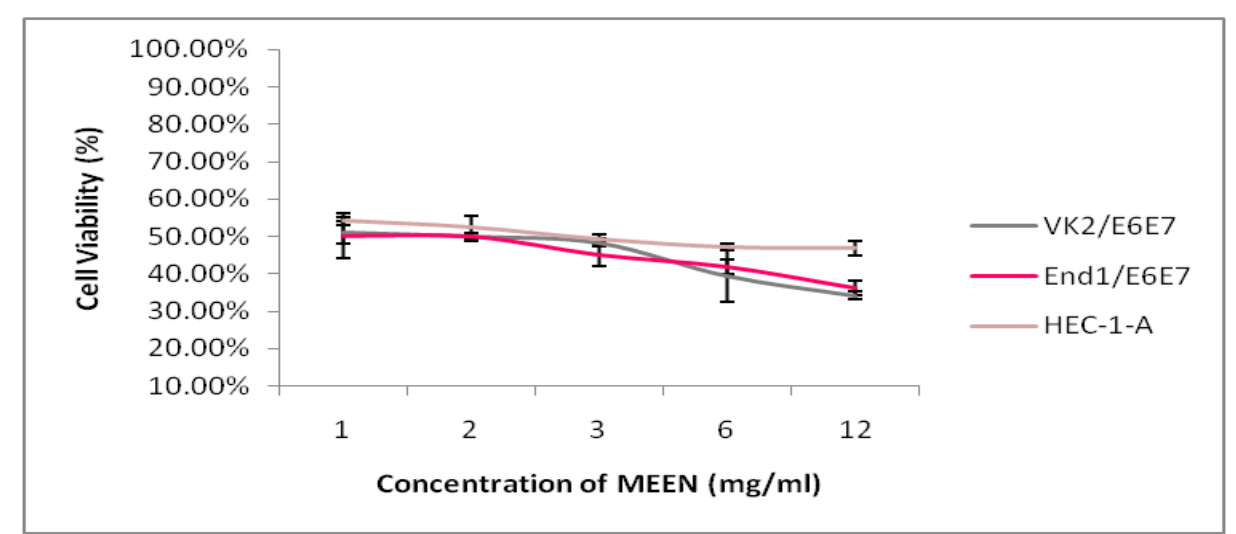

Figure 1: Effect of MEEN on the viability of vaginal, endocervical and endometrial epithelial cell lines as tested through MTT assay after $24 \mathrm{hrs}$ of treatment. Percentage viability of cells in presence of various concentrations of MEEN was measured after 24 hours of treatment. Values are calculated as mean \pm SD of three independent experimental trials where each condition was tested in duplicate.

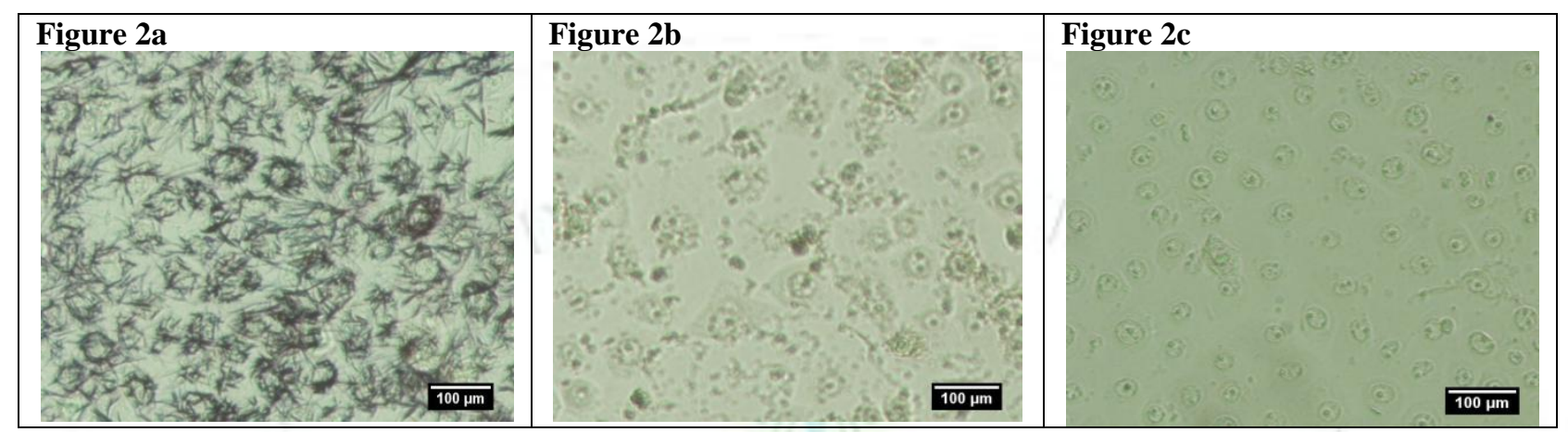

Figure 2: Microscopic observation of viability of vaginal epithelial cell line (VK2/E6E7) as tested through MTT assay after 24 hrs of treatment. (a) Untreated control, (b) MEEN ( $1 \mathrm{mg} / \mathrm{ml})$, (c) Positive control of cytotoxicity (0.1\% Triton X-100) (Magnification: 20X; Scale: $100 \mu \mathrm{m})$. When compared to untreated control, MEEN and Triton X-100 treated cells can be seen to have shrunken, rounded cells with lot of cell debris and ruptured cell membrane, formazan crystal formations are also rarely observed.

\section{Determination of transepithelial electrical resistance}

By growing HEC-1-A cells on Transwell inserts, a polarized epithelial cell monolayer with both apical and basolateral compartments was established (Table 2). On day $8^{\text {th }}$, confluent monolayer of HEC-1A cells were treated with various treatments for $24 \mathrm{hrs}$ and changes in TER values in comparison to a known cell death inducer
(0.1\% Triton $\mathrm{X}-100)$ were determined. In this test as well MEEN at a concentration of $1.0 \mathrm{mg} / \mathrm{ml}$ (T-En1.0) showed significant $(\mathrm{p}<0.01)$ reduction in TER values, comparable to the cell death inducer, indicating considerable cell death and monolayer disruption. Fig. 3a and 3b. shows the recording of TER values as the confluency increased and effect on TER values post treatment.

Table 2: Time dependent effect of MEEN on transepithelial electrical resistance (TER) on HEC-1-A cell monolayer. Monolayer integrity was measured through changes in TER values upon treatment with plant extracts. Values are calculated as mean \pm SD of three independent experimental trials.

\begin{tabular}{|c|c|c|c|c|}
\hline & & \multicolumn{3}{|c|}{ Resistance $\left(\Omega / \mathrm{cm}^{2}\right)($ Mean $\pm \mathrm{SD})$} \\
\hline \multicolumn{2}{|l|}{ Treatments } & UT & T-En1.0 & TX \\
\hline \multirow[t]{9}{*}{ Time (days) } & Day 1 & $32.67 \pm 8.39$ & $30.33 \pm 5.03$ & $32.67 \pm 3.21$ \\
\hline & Day 2 & $39.00 \pm 2.00$ & $37.67 \pm 4.51$ & $44.00 \pm 3.61$ \\
\hline & Day 3 & $44.00 \pm 3.00$ & $60.00 \pm 7.21$ & $70.67 \pm 2.52$ \\
\hline & Day 4 & $61.33 \pm 4.04$ & $72.33 \pm 2.08$ & $71.00 \pm 2.65$ \\
\hline & Day 5 & $67.33 \pm 2.52$ & $76.67 \pm 5.69$ & $74.33 \pm 4.04$ \\
\hline & Day 6 & $70.67 \pm 4.51$ & $82.00 \pm 6.56$ & $75.67 \pm 5.86$ \\
\hline & Day 7 & $85.67 \pm 1.53$ & $83.67 \pm 2.52$ & $85.33 \pm 3.51$ \\
\hline & Day 8 (before treatment) & $93.67 \pm 5.13$ & $98.00 \pm 4.00$ & $91.33 \pm 4.04$ \\
\hline & Day 9 (after treatment) & $92.67 \pm 3.06$ & $73.33 \pm 5.13$ & $47.00 \pm 2.00$ \\
\hline
\end{tabular}

UT, Untreated; T-En1.0, MEEN (1mg/ml); TX, 0.1\% Triton X-100.The significant effect of each treatment as compared to untreated control was carried out through $t$ test at significance level $(* * * \mathrm{p}<0.01)$. 
Figure 3a

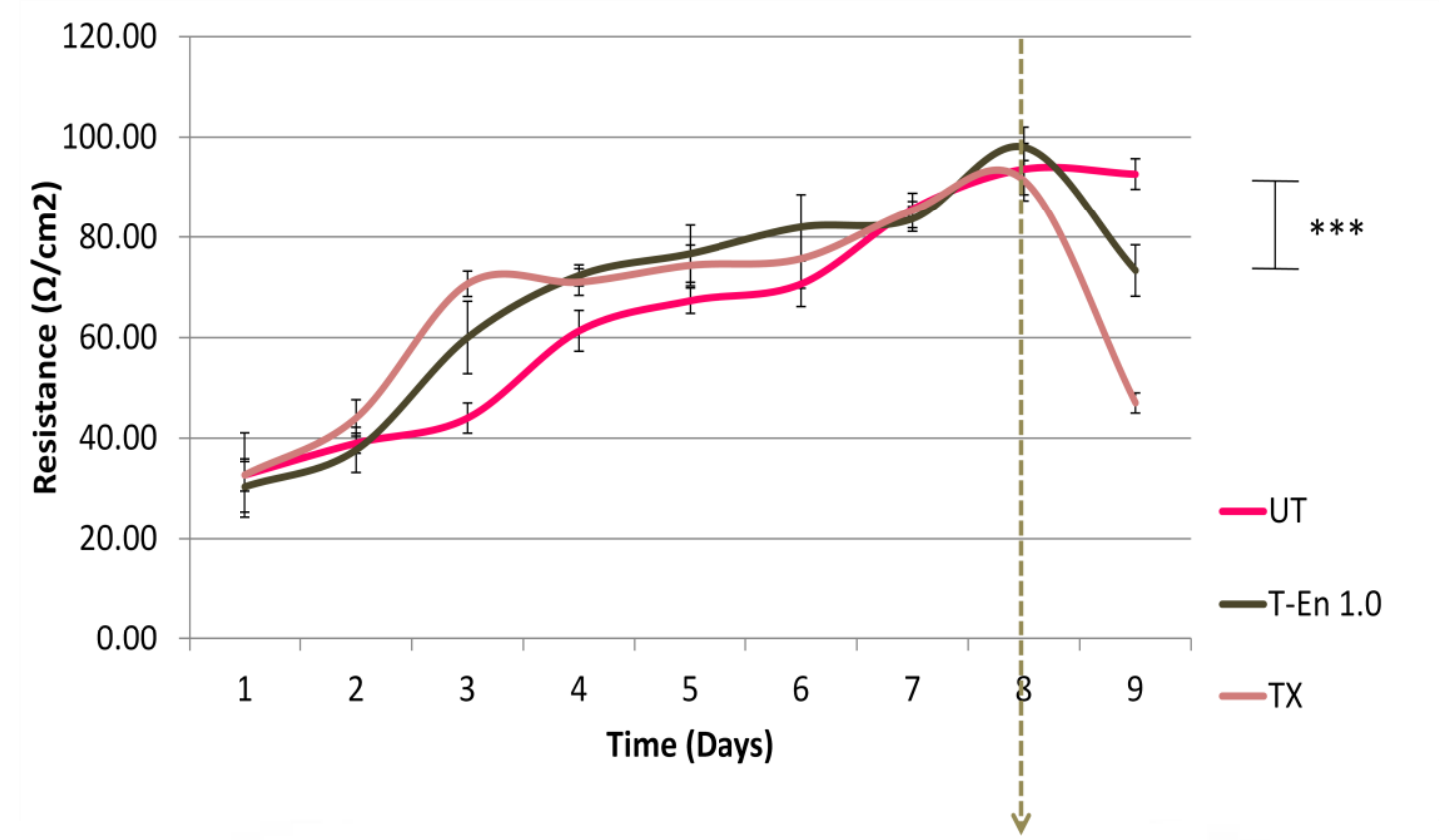

Time of Treatment

Figure 3b

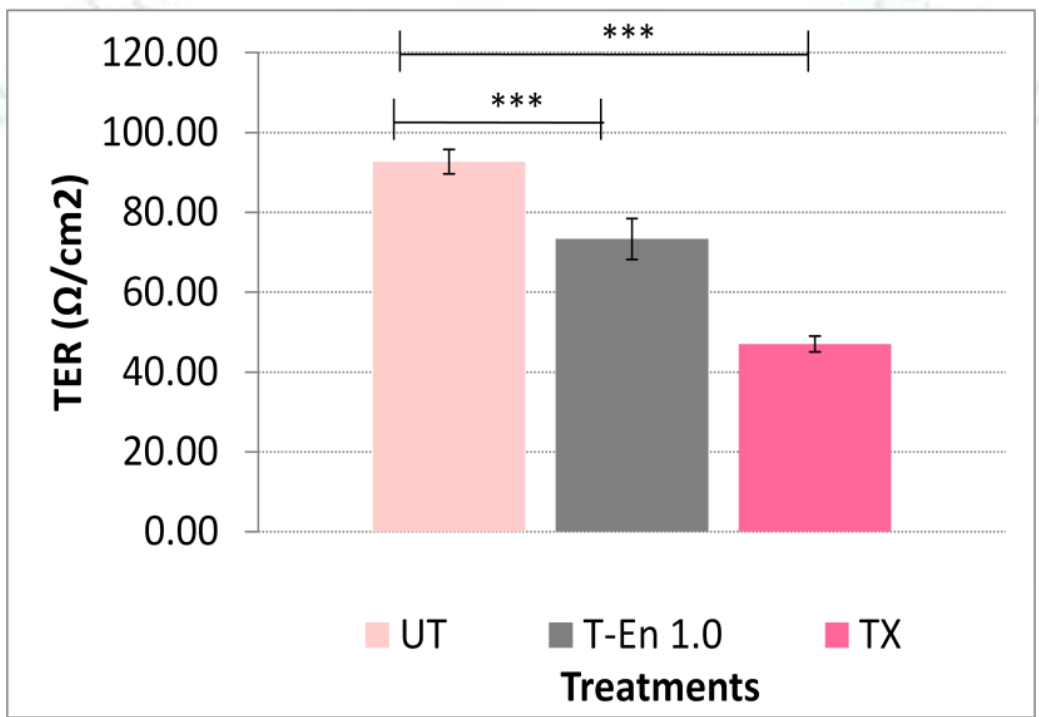

Figure 3: Time dependent effect of MEEN on transepithelial electrical resistance (TER) of HEC-1-A cell monolayer. a) TER values as measured on a daily basis till the $8^{\text {th }}$ day when monolayer was formed and TER values peaked. On $8^{\text {th }}$ day treatments were given and on $9^{\text {th }}$ day $(24 \mathrm{hrs})$ TER values were noted again to check for any drop in values signifying disruption of monolayer integrity. b) Comparison of TER values between untreated and treated groups on $9^{\text {th }}$ day. Values are calculated as mean \pm SD of three independent experimental trials. The significant effect of each treatment as compared to untreated control was carried out through $t$ test at significance level $(* * * p<0.01)$.

UT, Untreated; T- En1.0, MEEN (1mg/ml); TX, 0.1\% Triton X-100

\section{Permeability of fluorescent microspheres}

Enhanced fluorescence was observed for the background well containing media only without cell and cell death inducer $0.1 \%$ Triton $\mathrm{X}-100$, indicating $\mathrm{TX}$ to have extensively disrupted the confluent monolayer formed by HEC-1-A cells. As seen in Fig. 4, percentage fluorescence resulting from passage of fluorescently labeled microspheres at the 24 hour treatment time point were $29 \%$ for MEEN, indicating significant ( $p<0.01$ ) disruption in cellular integrity. 


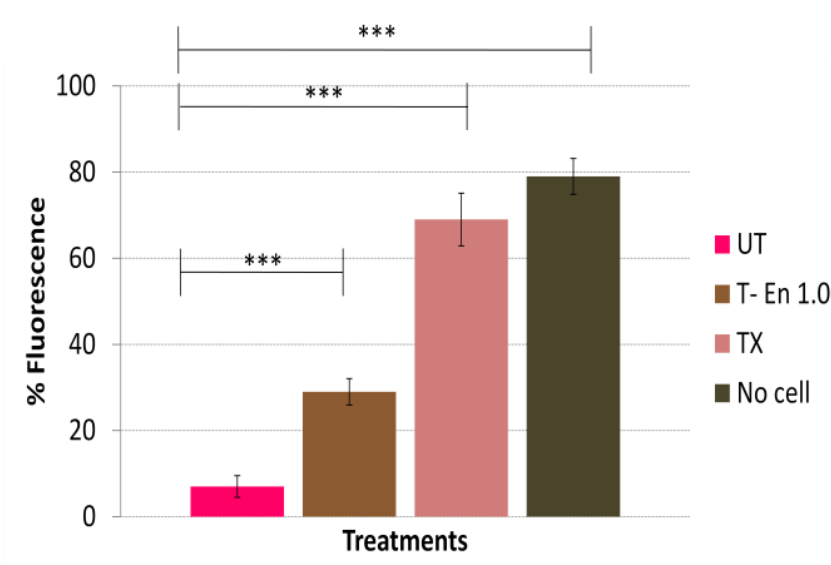

Figure 4: Graphical representation showing percentage fluorescence measured in the basal media due to permeation of fluorescent microsphere beads across polarized HEC-1-A monolayer. Values are calculated as mean $\pm \mathrm{SD}$ of three independent experimental trials. The significant effect of each treatment as compared to untreated control was carried out through t test at significance level $(* * * \mathrm{p}<0.01)$.

UT, Untreated; T- En1.0, MEEN (1mg/ml); TX, 0.1\% Triton X-100

\section{Hemolytic activity of MEEN}

Hemolytic activity of MEEN against HRBCs was evaluated at serial concentrations in the range of $0.1-20$ $\mathrm{mg} / \mathrm{ml}$ (Fig. 5). MEEN showed no hemolytic activity in the range of $0.1-2.5 \mathrm{mg} / \mathrm{ml}$, on the other hand at higher concentrations of $5-20 \mathrm{mg} / \mathrm{ml}$ MEEN showed considerable hemolysis in the $19 \%-31 \%$ range. Minimum hemolytic concentration that caused $10 \%$ hemolysis of HRBCs was determined to be $5.0 \mathrm{mg} / \mathrm{ml}$ for MEEN (Table 3 \& Fig. 6 ).

Table 3: Determination of Minimum hemolytic concentration. The concentration of MEEN which caused $10 \%$ hemolysis in human RBCs was taken as the minimum hemolytic concentration.

\begin{tabular}{|l|l|}
\hline Concentration of extract $\mathbf{( m g / m l )}$ & \% Hemolytic \\
\hline $\mathbf{0 . 1}$ & $0 \% \pm 0.00$ \\
\hline $\mathbf{0 . 2}$ & $0 \% \pm 0.00$ \\
\hline $\mathbf{0 . 3}$ & $0 \% \pm 0.00$ \\
\hline $\mathbf{0 . 6}$ & $0 \% \pm 0.00$ \\
\hline $\mathbf{1 . 2}$ & $0 \% \pm 0.00$ \\
\hline $\mathbf{2 . 5}$ & $0 \% \pm 0.00$ \\
\hline $\mathbf{5}$ & $\mathbf{1 9 . 2 5 \%} \pm \mathbf{0 . 0 3} *$ \\
\hline $\mathbf{1 0}$ & $28.92 \% \pm 0.02$ \\
\hline $\mathbf{2 0}$ & $31.47 \% \pm 0.06$ \\
\hline Untreated & $0 \% \pm 0.00$ \\
\hline $\mathbf{0 . 1 \%}$ Triton X-100 & $100 \% \pm 0.00$ \\
\hline
\end{tabular}

*Minimum hemolytic concentration

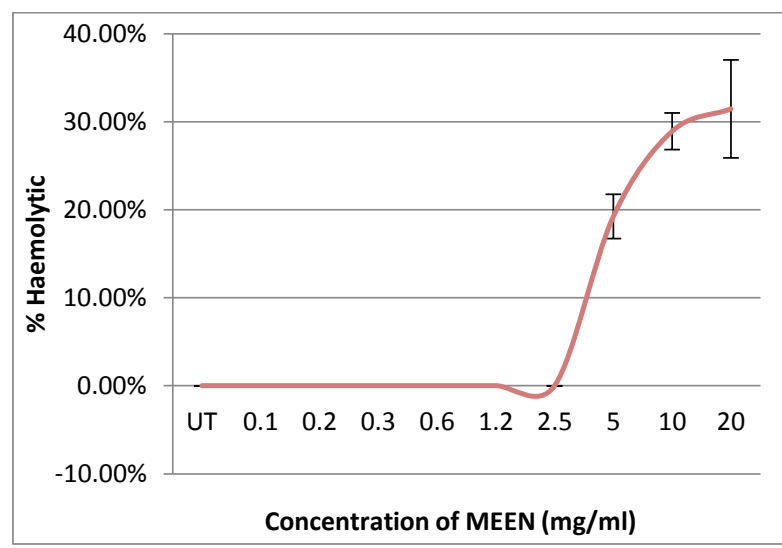

Figure 5: Effect of MEEN in inducing hemolysis in human RBCs. Values are calculated as mean \pm SD of three independent experimental trials.

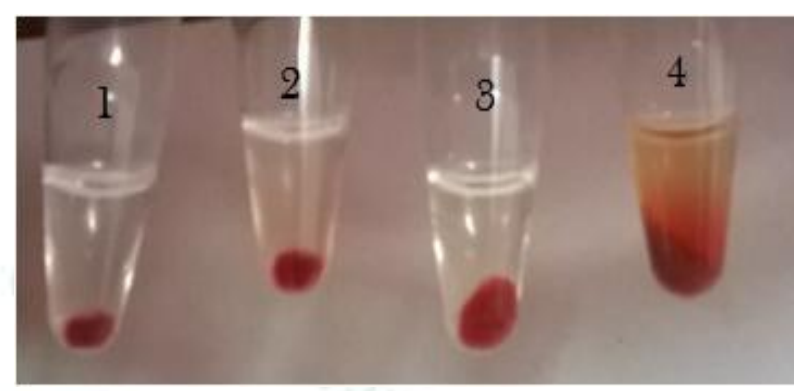

Figure 6: Effect of MEEN treatment on hemolysis of human RBCs. 1. Untreated control, 2. MEEN (2.5 $\mathrm{mg} / \mathrm{ml}), 3$. MEEN (5 mg/ml), 4. MEEN (10 mg/ml). Hemolysis was observed in the $3^{\text {rd }}$ and $4^{\text {th }}$ MEEN treated tubes as can be seen through diffused RBC pellets.

\section{DISCUSSION}

The study was undertaken with the aim of developing a microbicide from the herb Evolvulus nummularius, which is well-known for its medicinal properties. ${ }^{3-11}$ Since safety study is an essential early step in preclinical microbicide development, the safety of the methanolic crude extract of E. nummularius (MEEN) was tested in this paper.

For a future microbicidal candidate to be successful, in vitro results should mimic future in vivo results. For this reason a logical step is to select such cell types for cytotoxicity tests which are most likely to be involved during in vivo infection cycles. Since the exact mechanism of infection is still a mystery for most STI pathogens and also because an ideal microbicidal candidate is required to be effective against more than one STI pathogen, it is best to test the candidate compound on a variety of cell types focusing on those known to be targets for in vivo infection. Hence, vaginal (VK2/E6E7), endocervical (End1/E6E7) and endometrial (HEC-1-A) cell lines were chosen, which will likely be involved in in vivo infection cycles ${ }^{18}$ and are the target cells for developing a vaginal microbicide.

A microbicide for optimal activity needs to be applied frequently over a long period of time and it is essential that the compound does not cause abrasion or inflammation to the host tissue. Therefore cell viability assay using MTT assay on vaginal epithelial cell lines and a hemolytic assay on human RBCs were performed. 
Following MTT treatment, after a period of $24 \mathrm{hrs}$ with MEEN at concentration range of $1 \mathrm{mg} / \mathrm{ml}-12 \mathrm{mg} / \mathrm{ml}$, microscopic observation showed extensive cell death with cell disruption, breakage of cell to cell adhesion and very few intracellular formazan crystals. While the $\mathrm{IC}_{50}$ of VK2/E6E7 and HEC-1-A cells were $2 \mathrm{mg} / \mathrm{ml}$, $\mathrm{IC}_{50}$ of End1/E6E7 was even lower at $1 \mathrm{mg} / \mathrm{ml}$. Cell mortality was comparable to the commonly used cytotoxic compound Triton X-100. In the hemolytic assay, after treating with MEEN for one hour, MEEN did not show hemolysis till the concentration of 2.5 $\mathrm{mg} / \mathrm{ml}$. However at higher concentrations ranging from $5 \mathrm{mg} / \mathrm{ml}$ to $20 \mathrm{mg} / \mathrm{ml} 20 \%$ to $30 \%$ hemolysis were observed.

In TER and microsphere permeability assays, polarized HEC-1-A monolayer were set up in dual chamber Transwell units mimicking the in vivo epithelial barrier. Also mimicking natural infection by STI causing pathogens were the fluorescent microspheres used in the permeability assay which were of $100 \mathrm{~nm}$ diameter, a dimension similar to that of HIV- 1 virus particles. As would be done in the application of a microbicide, MEEN was applied onto the apical side only for 24 hours. A significant drop in electrical resistance as measured through TER and enhanced fluorescence from passage of microspheres from the apical to the basal chamber compared to the control well implied cell death, which in in vivo system would translate to disruption of the epithelial layer and passage of STI pathogens.

Although several plant extracts may have medicinal value, their therapeutic potential is known to depend on various other factors. Secondary metabolites can cause toxicity to cells at concentrations demonstrating inhibition of bacterial growth. In this study, phytochemical analysis of E. nummularius was found to contain saponins, triterpenoids and cardiac glycosides in high concentrations. Saponins and triterpenoids have both been studied to have cytotoxic effect. The presence of saponins which if present in high concentration may disrupt cellular membranes and cause cellular toxicity and hemolysis. ${ }^{19}$ Triterpenoids in several studies have

\section{REFERENCES}

1. Shaw D 1998. Risks or remedies? Safety aspects of herbal remedies in the UK. J. Roy. Soc. Med. 1998; 91:294-296.

2. Lanini, J, Duarte-Almeida JM, Nappo SA, Carlini EA. Are medicinal herbs safe? The opinion of plant vendors from Diadema (São Paulo, southeastern Brazil). Braz. J. Pharmacogn. 2012; 22:21-28.

3. Jain SK. Dictionary of Indian folk medicine and ethnobotany. Deep publication, New Delhi. 1991; p. 92.

4. Manandhar NP, Manandhar S. Plants and People of Nepal. Timber Press. 2002. p. 230.

5. Saini V, Kinger HK, Sharma DK, Ahuja N, Middha A, Gupta VB. Wound healing activity of Evolvulus numularius Linn. Asian J. Chem. 2007; 19:5772-4

6. Chitralekha C, Dey PK, Dey CD. Pharmacological screening of Valeriana wallichii Lallemantia royleana, Breynia rhamnoides and Evolvulus nummularius for sedative and anti-convulsant principles. Naturwissenschaften. 1964; $51: 411$.

7. Anisuzzaman M, Rahman AHMM, Harun-Or-Rashid M, Naderuzzaman ATM, Islam AKMR. An Ethnobotanical shown specific toxicity towards cancer cell lines, ${ }^{20}$ however, in certain studies they have shown cytotoxicity to normal cells of the human body too. ${ }^{21-23}$

Drawbacks of this study and studies in general on plant extracts as microbicidal study candidates are batch to batch variations on presence of secondary metabolites which may be due to season of collection, phenological age of the plant, climatic and abiotic factors. Future studies therefore should focus on methods to identify the pure compound responsible for its antimicrobial activity, which can avoid such problems as batch to batch variations, and also pure compounds can be expected to be effective at much lower concentrations.

\section{CONCLUSION}

In conclusion, though we started out with the aim of developing a microbicide from the plant $E$. nummularius whose medicinal properties have been well documented, in vitro safety studies showed the methanolic extract of the plant to be highly toxic towards human red blood cells and female genital tract epithelial cells. $E$. nummularius extract has many applications in folk medicine. Due to its highly toxic nature, its applications where applied directly to the human epithelium such as to treat burns and cuts, ${ }^{3}$ as a treatment for scabies when applied as a paste, ${ }^{4}$ as a wound healing compound, ${ }^{5}$ and as a paste to treat peptic ulcer ${ }^{7}$ should be done with extreme caution and safety studies should be conducted using appropriate cell types.

\section{ACKNOWLEDGEMENT}

The authors thank the Department of Biotechnology under Ministry of Science and Technology, India for funding the study and Dr. Tapan Majumdar (Associate Professor, Department of Microbiology, Agartala Government Medical College, Kunjavan, Agartala, Tripura) for his scientific advice and guidance. The authors also thank Prof. Badal Kumar Datta, Taxonomist, Department of Botany, Tripura University for his help with identification of the plant.

\section{Conflict of Interest: Nil}

Study of Madhupur, Tangail. Journal of Applied Sciences Research. 2007; 3:519-530.

8. Mia MM, Kadir MF, Hossan MS, Rahmatullah M. Medicinal plants of the Garo tribe inhabiting the Madhupur forest region of Bangladesh. Am.-Eurasian J. Sustain. Agric. 2009; 3:165-171.

9. Pavithra PS, Sreevidya N and Verma RS. Antibacterial and antioxidant activity of methanol extract of Evolvulus nummularius. Indian J. Pharmacol. 2009; 41:233.

10. Dash GK, Bijayini M, Panda A, Patro CP, Ganapaty S. Antihelmintic activity of Evolvulus nummularius. Indian J. Nat. Prod. 2003; 19:24-6.

11. Saha R, Dinda B, Sil SK. Growth inhibitory effect of Evolvulus nummularius extract on Leishmania donovani parasite. J. Ecobiol. 2010; 27:335-340.

12. Fichorova RN, Rheinwald JG, Anderson DJ. Generation of papillomavirus-immortalized cell lines from normal human ectocervical, endocervical, and vaginal epithelium that maintain expression of tissue-specific differentiation proteins. Biol. Reprod. 1997; 57: 847-855. 
13. Kurarmoto H, Hamano M, Imai M. HEC-1 cells. Hum. Cell. 2002; 15:81-95.

14. Sathe A, Reddy KVR. TLR9 and RIG-I Signaling in Human Endocervical Epithelial Cells Modulates Inflammatory Responses of Macrophages and Dendritic Cells In Vitro. PLoS ONE. 2014; 9: e83882.

15. Vijayarathna S, Sasidharan S. Cytotoxicity of methanol extracts of Elaeis guineensis on MCF-7 and Vero cell lines. Asian Pac J Trop Biomed. 2012; 2: 826-9.

16. Gali Y, Delezay O, Brouwers J, Addad N, Augustijns P, Bourlet $\mathrm{T}$ et al. In vitro evaluation of viability, integrity, and inflammation in genital epithelia upon exposure to pharmaceutical excipients and candidate microbicides. Antimicrob. Agents Chemother. 2010; 54:5105-14.

17. Dong, N, Ma Q, Shan A, Lv Y, Hu W, Gu Y et al. Strand Length-Dependent Antimicrobial Activity and MembraneActive Mechanism of Arginine- and ValineRich betaHairpin-Like Antimicrobial Peptides. Antimicrob. Agents Chemother. 2012; 56:2994-3003
18. Piret J, Desormeaux A, Bergeron MG. Sodium lauryl sulfate, a microbicide effective against enveloped and nonenveloped viruses. Curr. Drug Targets. 2002; 3:17-30.

19. Top H, Sarikahya NB, Nalbantsoy A, Kirmizigul S. Immunomodulatory, hemolytic properties and cytotoxic activity potent of triterpenoid saponins from Cephalaria balansae. Phytochemistry. 2017; 137:139-147.

20. Chudzik M, Korzonek-Szlacheta I, Wojciech K. Triterpenes as Potentially Cytotoxic Compounds. Molecules. 2015; 20:1610-1625.

21. Ragasa CY, Cornelio KB. Triterpenes from Euphorbia hirta and their cytotoxicity. Chin. J. Nat. Med. 2013; 11:528-533.

22. Mokoka TA, McGaw LJ, Mdee LK, Bagla VP, Iwalewa EO, Eloff JN. Antimicrobial activity and cytotoxicity of triterpenes isolated from leaves of Maytenus undata (Celastraceae). BMC Complement. Altern. Med. 2013; $13: 111$.

23. Zhang H, Samadi AK, Rao KV, Cohen MS, Timmermann BN. Cytotoxic oleanane-type saponins from Albizia inundata. J. Nat. Prod. 2011; 74:477-482. 